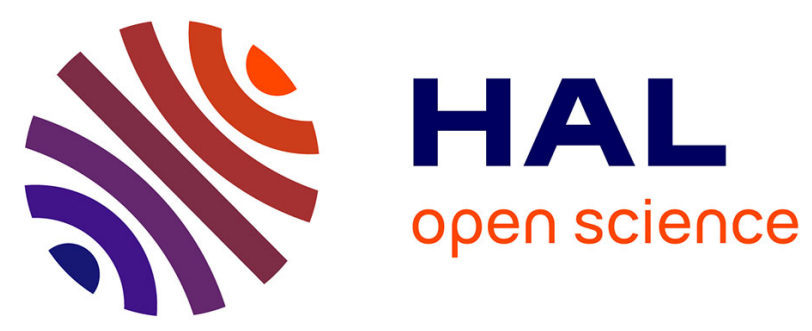

\title{
Transfer of singlet oxygen from senescent irradiated phytoplankton cells to attached heterotrophic bacteria: Effect of silica and carbonaceous matrices
}

Morgan Petit, Maxime Suroy, Richard Sempere, Frederic Vaultier, John K. Volkman, M. Goutx, Jean-Francois Rontani

\section{To cite this version:}

Morgan Petit, Maxime Suroy, Richard Sempere, Frederic Vaultier, John K. Volkman, et al.. Transfer of singlet oxygen from senescent irradiated phytoplankton cells to attached heterotrophic bacteria: Effect of silica and carbonaceous matrices. Marine Chemistry, 2015, 171, pp.87-95. 10.1016/j.marchem.2015.02.007 . hal-01164658

\author{
HAL Id: hal-01164658 \\ https://hal.science/hal-01164658
}

Submitted on 25 Feb 2019

HAL is a multi-disciplinary open access archive for the deposit and dissemination of scientific research documents, whether they are published or not. The documents may come from teaching and research institutions in France or abroad, or from public or private research centers.
L'archive ouverte pluridisciplinaire HAL, est destinée au dépôt et à la diffusion de documents scientifiques de niveau recherche, publiés ou non, émanant des établissements d'enseignement et de recherche français ou étrangers, des laboratoires publics ou privés. 


\title{
Transfer of singlet oxygen from senescent irradiated phytoplankton cells to attached heterotrophic bacteria: Effect of silica and carbonaceous matrices
}

\author{
Morgan Petit ${ }^{\mathrm{a}, *}$, Maxime Suroy ${ }^{\mathrm{a}}$, Richard Sempéré ${ }^{\mathrm{a}}$, Frédéric Vaultier ${ }^{\mathrm{a}}$, John K. Volkman ${ }^{\mathrm{b}}$, \\ Madeleine Goutx ${ }^{\mathrm{a}}$, Jean-François Rontani ${ }^{\mathrm{a}}$ \\ a Aix-Marseille Université, Mediterranean Institute of Oceanography (MIO), 13288, Marseille, Cedex 9; Université du Sud Toulon-Var, 83957, CNRS-INSU/IRD UM 110, France \\ b CSIRO Oceans and Atmosphere Flagship, GPO Box 1538, Hobart, Tasmania 7001, Australia
}

\section{A R T I C L E I N F O}

\section{Article history:}

Received 13 January 2014

Received in revised form 14 February 2015

Accepted 16 February 2015

Available online 20 February 2015

\section{Keywords:}

Singlet oxygen transfer

Photooxidation

Silica and carbonaceous matrices

Bacteria

Diatoms

Coccolithophorids

Phytoplankton

\begin{abstract}
A B S T R A C T
The effect of silica and carbonaceous matrices (charged mineral surfaces) in phytoplankton cells on the transfer of singlet oxygen from irradiated phytodetritus to their attached bacteria was investigated under controlled laboratory conditions. Our results indicate that a silica matrix (i.e. as in diatom frustules) inhibits the transfer of singlet oxygen and limits the induced photodegradation of cis-vaccenic acid (a fatty acid generally considered as specific to bacteria). In contrast, a carbonaceous matrix (i.e. as in coccoliths) does not seem to inhibit the transfer probably due to the release of coccoliths upon cell death. As a consequence, bacteria associated with phytodetritus from diatoms should be in a healthy state and biodegradation of organic matter associated with these particles should be favoured. These results should contribute to a better understanding of photosensitized degradation processes and to a better estimation of the balance between degradation and preservation of organic material during sedimentation in seawater.
\end{abstract}

\section{Introduction}

Particulate organic matter (POM) consisting mainly of phytodetritus in the euphotic layer of oceans is recycled in surface waters within the food web and the microbial loop. Only a small part is exported by particles which fall to the deep ocean and thus serve as the primary vehicle by which carbon is exported to the deep ocean and seafloor (Boyd and Trull, 2006; Thunell et al., 2007). It is thus very important to understand the mechanisms by which this organic matter $(\mathrm{OM})$ is degraded. Although the importance of photooxidative and autoxidative processes (abiotic processes) of POM degradation in the marine environment has been experimentally demonstrated (Rontani et al., 2011), there is a paucity of data concerning these processes. Indeed, most assessments of POM export from the euphotic layer to the deep ocean only consider biotic degradation processes including zooplankton grazing and enzymatic degradation by attached and free living heterotrophic bacteria (Goutx et al., 2007; Sempéré et al., 2000; Tamburini et al., 2009; Turley and Mackie, 1994). Ghiglione et al. (2007) previously showed that the contribution of attached bacteria to total bacterial activity can reach up to
$83 \%$ under mesotrophic conditions. We could recently confirm these results in a culture of the haptophyte Emiliania huxleyi in late stationary phase (Petit et al., 2015). Indeed, quantitative PCR analyses allowed us to demonstrate that more than $90 \%$ of bacteria were attached to E. huxleyi cells.

During the senescence of phototrophic organisms, visible light and UV-induced photosensitized degradation processes act intensively due to the presence of a very efficient photosensitizer: chlorophyll (Foote, 1976; Knox and Dodge, 1985). These processes mainly involve singlet oxygen $\left({ }^{1} \mathrm{O}_{2}\right)$ and act on most of the unsaturated lipid components (including sterols, unsaturated fatty acids, and the chlorophyll phytyl side chain) of these organisms, producing allylic hydroperoxides (Christodoulou et al., 2010; Rontani, 2001).

The effects of photooxidation, however, are not limited to chloroplasts; indeed, during the natural senescence of higher plants, ${ }^{1} \mathrm{O}_{2}$ can migrate outside the chloroplasts and chemically react with unsaturated components of cuticular waxes (Rontani et al., 2005). In the case of senescent phytoplanktonic cells, ${ }^{1} \mathrm{O}_{2}$ can induce the degradation of heterotrophic bacteria attached to particles. Indeed, recent results demonstrated that singlet oxygen has a much larger intracellular sphere of activity than previously thought (Ogilby, 2010). Most of the calculated values of the radius of singlet oxygen's sphere of activity from its point of production (ranging from 155 to 
340 nm; Baier et al., 2005; Ogilby, 2010; Skovsen et al., 2005; Wilkinson et al., 1995) are sufficiently large to allow singlet oxygen, if produced near the cell membrane, to be able to cross over into the extracellular environment (Ogilby, 2010) and thus reach any attached bacteria. Cellular damage resulting from the transfer of substantial amounts of ${ }^{1} \mathrm{O}_{2}$ from phytoplanktonic cells to their attached heterotrophic bacteria may be substantial due to the lack of efficient photoprotective and antioxidant systems in these microorganisms (Garcia-Pichel, 1994) and this can affect their capability to degrade POM. Such a transfer of ${ }^{1} \mathrm{O}_{2}$ to bacteria has also been observed in situ in several POM samples (Christodoulou et al., 2009; Marchand and Rontani, 2001; Marchand et al., 2005; Rontani et al., 2011) and may help to explain the relative recalcitrance of already strongly abiotically degraded suspended POM towards further biotic degradation (Rontani et al., 2011).

The lifetime of ${ }^{1} \mathrm{O}_{2}$ in hydrophobic environments is longer, and its potential diffusive distance greater, than under hydrophilic conditions (Suwa et al., 1977). Charged mineral surfaces including silica matrices (e.g. diatom frustules) or carbonate matrices (e.g. coccoliths) could reduce the lifetime of ${ }^{1} \mathrm{O}_{2}$ and inhibit its migration to bacterial biomass. Indeed, if the transfer of ${ }^{1} \mathrm{O}_{2}$ is strongly favoured between two lipophilic membranes (such as those of phytoplankton and associated bacteria; Petit et al., 2013), this excited form of oxygen might be quickly deactivated if the two membranes are separated by a polar structure. Thus charged mineral surfaces, such as frustules or coccoliths, may allow for enhanced bacterial growth and biodegradation of phytodetritus by inhibition of ${ }^{1} \mathrm{O}_{2}$ transfer. It may be noted that transparent exopolymer particles (TEP), which are mainly composed of polysaccharides (Smith et al., 1995) and act as the glue for particle aggregation (Gärdes et al., 2011), may also (due to their polar character) inhibit ${ }^{1} \mathrm{O}_{2}$ transfer to bacteria.

Diatoms and coccolithophorids are two major groups in present-day marine phytoplankton. Diatoms are ubiquitous photosynthetic eukaryotes that are responsible for about $35 \%$ of the primary production of the oligotrophic oceans and 75\% in the coastal zone and other nutrient-rich systems (Nelson et al., 1995). These cells build a rigid cell wall made of amorphous silica (frustules) that cause them to sink rapidly when the cells die or during senescence, carrying fixed organic carbon to the deep ocean. Thalassiosira weissflogii is a centric diatom occurring in coastal waters in the Atlantic and Pacific Oceans, as well as brackish and freshwater environments. Coccolithophorids, belonging to the algal class Prymnesiophyceae, are able to produce scales made of calcium carbonate called coccoliths. E. huxleyi is the most ubiquitous living coccolithophorid species in the ocean (Westbroek et al., 1984) and occurs in most of the oceanic subsurface (Honjo and Okada, 1974; Okada and Honjo, 1973) from polar to equatorial areas. This species is often present in high density $\left(5 \times 10^{3}\right.$ cell $\left.\mathrm{L}^{-1}\right)$ and can form large blooms particularly in temperate and subarctic latitudes (Brown and Yoder, 1994). Consequently E. huxleyi plays an important part in the oceanic carbon cycle as a primary producer, contributing to the organic matter stock in marine sediments (Marlowe et al., 1990). Dunaliella tertiolecta (Chlorophyceae) is a naked cell (lack of a rigid cell wall) ranked among the most photophilic algae (Richardson et al., 1983). This species thrives in hypersaline, marine and freshwater habitats (Ben-Amotz and Avron, 1992).

In this study, we (i) compared the ${ }^{1} \mathrm{O}_{2}$ transfer from senescent diatom cells, coccolithophorid cells and free rigid wall chlorophyte cells to their attached bacteria, and (ii) monitored the effect of the biogenic silica concentration of the diatom frustules on ${ }^{1} \mathrm{O}_{2}$ transfer. For this purpose, the photooxidation of cis-vaccenic acid ( $C_{18: 1 \Delta 11}$; a fatty acid typical of Gram-negative bacteria; Sicre et al., 1988; Keweloh and Heipieper, 1996) in non-axenic senescent cultures of the haptophyte E. huxleyi, diatoms T. weissflogii, Navicula sp. cf. jeffreyi and Skeletonema sp. cf. costatum and the green alga D. tertiolecta was investigated under controlled laboratory conditions.

\section{Methods}

\subsection{Photodegradation experiments}

Two kinds of photodegradation experiments were conducted. The aim of the first one was to compare the effect of the matrices of Navicula cf. jeffreyi type, E. huxleyi, D. tertiolecta and Skeletonema cf. costatum on photodegradation where samples (one replicate for each point) were directly irradiated by artificial light with an Atlas Suntest solar simulator under an irradiance of $500 \mathrm{~W} \mathrm{~m}^{-2}$ in the $280-700 \mathrm{~nm}$ wavelength range. The second experiment was conducted to investigate the effect of biogenic silica (bSi) concentration of $T$. weissflogii where 5 triplicate samples taken during 3 weeks of growth (at days 0, 6, 13, 15 and 20) were stored at $-20^{\circ} \mathrm{C}$ (freezing/thawing cycles do not significantly affect the frustule of T. weissflogii; Bidle and Azam, 2001) until irradiated (for $4 \mathrm{~h}$ ). In both experiments, Pyrex flasks (that limited irradiations to UVA + PAR, i.e. $\lambda>300 \mathrm{~nm}$ ) containing culture samples were irradiated by artificial light with an Atlas Suntest solar simulator under an irradiance of $500 \mathrm{~W} \mathrm{~m}^{-2}$ in the $280-700 \mathrm{~nm}$ wavelength range. The flasks were maintained at $17{ }^{\circ} \mathrm{C}$ by submersion in a water bath connected to a cryothermostat. Flasks were also kept under darkness at $17{ }^{\circ} \mathrm{C}$ as controls over the time course experiment (one replicate per point).

\subsection{Production of algal material}

E. huxleyi strain RCC1215 (with coccoliths, carbonaceous matrix) from Roscoff marine station culture collection, Skeletonema cf. costatum (silica matrix) strain RCC70 (Roscoff), D. tertiolecta (no matrix) strain RCC6 (Roscoff) and Navicula cf. jeffreyi (silica matrix) strain CS513 from the CSIRO Algal Culture Collection were grown in $500 \mathrm{~mL}$ of $\mathrm{f} / 2$ medium under non-axenic conditions at $17{ }^{\circ} \mathrm{C}$, in a constant environmentally controlled cabinet under an irradiance of $36 \mathrm{~W} \mathrm{~m}^{-2}$ (Osram, Fluora, 12:12 hour light:dark cycle), until stationary phase. Senescence was induced by transfer of the cells (after centrifugation at $3500 \mathrm{rpm}$ for $5 \mathrm{~min}$ ) to $500 \mathrm{~mL}$ of old natural seawater (collected several months previously) followed by incubation for 4 days. The cells employed during the experiments were senescent, except in the case of $D$. tertiolecta which were dead. Indeed, it was not possible to induce senescence in this alga by transfer in seawater, incubation under darkness or freezing-thawing cycles so it was killed with mercuric chloride (final concentration $2.5 \times 10^{-4} \mathrm{M}$ ).

In parallel, synchronous growth of $T$. weissflogii (silica matrix) strain AC813 from Caen Culture Collection was obtained by removing silicate from the medium which is well known to stop the cell cycle (Hildebrand et al., 2007). First $2 \mathrm{~L}$ of starter culture was grown in $\mathrm{f} / 2$ medium (with silicate) under the conditions above described, until stationary phase. Then $200 \mathrm{~mL}$ of this starter culture was centrifuged (3500 rpm for $5 \mathrm{~min}$ ), cells were washed with $10 \mathrm{~mL}$ of filtered sea water and transferred in $2 \mathrm{~L}$ of silica-free $\mathrm{f} / 2$ medium in a Nalgene flask. After $24 \mathrm{~h}$ under these growth conditions, $0.5 \mathrm{~mL}$ of $\mathrm{NaSiO}_{3}$ solution was added (final concentration $200 \mu \mathrm{mol} \mathrm{L}{ }^{-1}$ ) and diatom growth followed over time for 3 weeks.

It may be noted that during the different experiments the production of TEP was not favoured by the presence of EDTA in the $\mathrm{f} / 2$ medium (Decho, 1990), the lack of nutrient limitation (Malejl and Harris, 1993) and the shaking (Thornton, 2002). Moreover, the strain employed during the study of the effect of biogenic silica concentration on the transfer of singlet oxygen (T. weissflogii) does not aggregate (Kiørboe and Hansen, 1993).

\subsection{Biogenic silica and dissolved silica concentration}

The particulate biogenic silica (bSi) concentration for the T. weissflogii photodegradation experiment was determined using a variation of the method of Ragueneau and Tréguer (1994). As no 
lithogenic silica was present in the algal cultures, the second digestion step using hydrofluoric acid was not necessary. Triplicate samples of bSi were collected by filtration of $20 \mathrm{~mL}$ of culture on a polycarbonate (PC) membrane ( $0.4 \mu \mathrm{m}$ porosity, $47 \mathrm{~mm}$ diameter). PC membranes were submitted to alkaline digestion with $10 \mathrm{~mL}$ of $0.2 \mathrm{~mol} \mathrm{~L}^{-1} \mathrm{NaOH}$ in a $15 \mathrm{~mL}$ Eppendorf tube (previously washed with $10 \% \mathrm{HCl}$ solution) at $95{ }^{\circ} \mathrm{C}$ for $4 \mathrm{~h}$ to ensure the dissolution of all bSi in $\mathrm{Si}(\mathrm{OH})_{4}(\mathrm{dSi})$. After cooling, $2.5 \mathrm{~mL}$ of $1 \mathrm{~mol} \mathrm{~L}^{-1} \mathrm{HCl}$ was added to stop the digestion by neutralizing the $\mathrm{pH}$ before analysis of the $\mathrm{Si}(\mathrm{OH})_{4}$ concentration. Dissolved silica ( $\mathrm{dSi}$ ) was determined by analysing the filtrate from the bSi sample; bSi and dSi concentrations were estimated by the acid/molybdate colorimetric method described by Aminot and Kérouel (2004)

\subsection{Flow cytometer analysis}

For the T. weissflogii photodegradation experiment, $2 \mathrm{~mL}$ samples were taken each hour during the first day of Si replenishment then daily at the same hour of replenishment (days $0,1,3,7,8,9,10,13$, $14,15,16,18,20$ and 21 ) during the culture growth until stationary phase (Fig. 1). These samples were fixed with $20 \mu \mathrm{L}$ of glutaraldehyde solution (final concentration 1\%) then placed in liquid nitrogen until flow cytometer analysis for cell abundance and cycle phase determination.

Samples were analysed using a FACSCalibur (BD Biosciences ${ }^{\circledR}$ ), equipped with a blue (488 $\mathrm{nm}$ ) air-cooled argon laser. In the present study, the red fluorescence (653-669 nm, ChloroA) was used to measure chlorophyll $a$. Phytoplankton cells were characterised by 3 other optical signals: forward scatter (FSC) related to cell size, side scatter (SSC) related to cell structure and orange fluorescence (564-606 nm; PE) related to phycoerythrin. Data were collected using CellQuest software (BD Biosciences ${ }^{\circledR}$ ) and the analysis of ultraphytoplankton groups was performed a posteriori using SUMMIT v4.3 software (Beckman Coulter). TruCount beads (BD Biosciences ${ }^{\circledR}$ ) were added to the fixed samples to determine the volume analysed. The $2 \mu \mathrm{m}$ beads were used as internal standard and to discriminate between populations of picoplankton $(<2 \mu \mathrm{m})$ and nanoplankton $(>2 \mu \mathrm{m})$ (both Fluoresbrite YG, Polyscience). To ensure an efficient synchronisation of the culture, $1.5 \mu \mathrm{L}$ of PicoGreen ${ }^{\circledR}$ was added to each fixed subsample $(300 \mu \mathrm{L})$ to stain double stranded DNA and to quantify it by flow cytometry. Cell cycle phases were optically resolved from the red fluorescence versus PicoGreen ${ }^{\circledR}$ green fluorescence $(530 \mathrm{~nm}$ )

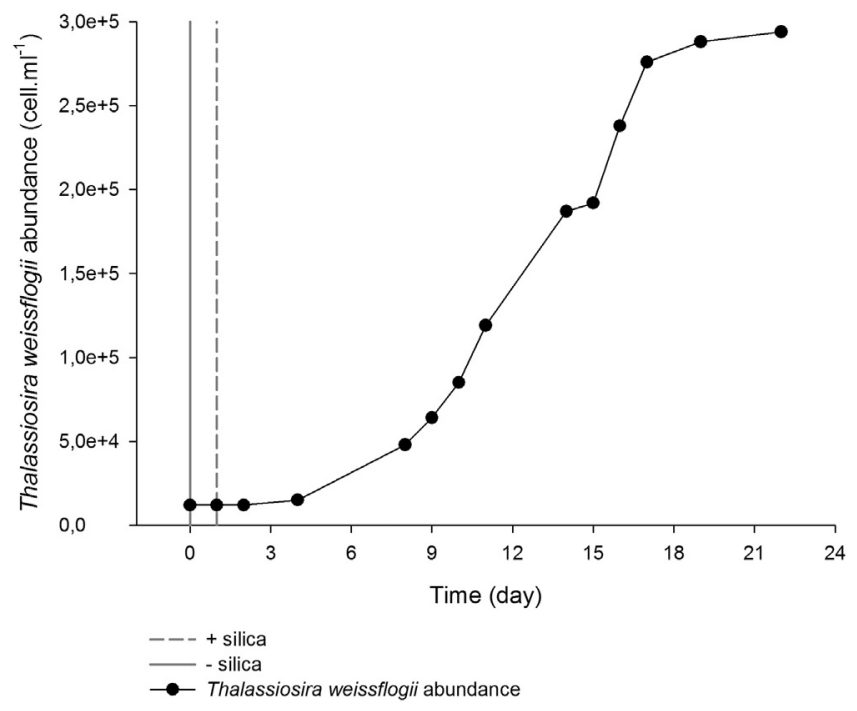

Fig. 1. Cell abundance (cell $\mathrm{mL}^{-1}$, determined by flux cytometer analysis) during the growth of $T$. weissflogii in $\mathrm{f} / 2$ medium under an irradiance of $36 \mathrm{~W} \mathrm{~m}^{-2}$ (12:12 hour light:dark cycle). by manual calculation. DNA amounts oscillated between $\mathrm{n}$ and $2 \mathrm{n}$ reflecting cells in G1 or G2 + M phases (Veldhuis et al., 2001).

\subsection{Chlorophyll a analysis}

Samples ( $5 \mathrm{~mL}$ ) were filtered through $25 \mathrm{~mm} \mathrm{GF} / \mathrm{F}$ filters (previously

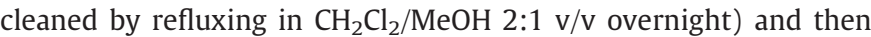
the filters were transferred into a glass tube and stored at $-20{ }^{\circ} \mathrm{C}$. After adding $5 \mathrm{~mL}$ of pure $\mathrm{MeOH}$ (Fisher Scientific, Loughborough, UK), the tube was closed and the extraction was performed in darkness at $4{ }^{\circ} \mathrm{C}$ for $30 \mathrm{~min}$. The sample fluorescence was directly measured with a Turner Designs fluorometer equipped with a F4T5 Blue lamp, a 5-60 $(450 \mathrm{~nm})$ excitation filter and a 2-64 (660 nm) high-pass emission filter. The fluorometer was calibrated with pure chlorophyll $a$ (Sigma C5753, St. Louis, MO, USA) dissolved in $\mathrm{MeOH}$ (96\%). The concentration of this solution was determined by spectrophotometry using the specific absorption coefficient of $77 \mathrm{~L} \mathrm{~g}^{-1} \mathrm{~cm}^{-1}$ at $663 \mathrm{~nm}$ (Marker, 1972). Correcting for phaeopigment interferences was performed using the acidification method (Holm-Hansen et al., 1965), which required a second fluorescence measurement after adding $50 \mu \mathrm{L}$ of $\mathrm{HCl}(0.5 \mathrm{~N})$ to the extract.

\subsection{Lipid analysis}

After irradiation, a known volume of the irradiated culture was filtered through $47 \mathrm{~mm} \mathrm{GF} / \mathrm{F}$ (Whatman, Maidstone, UK) filters for lipid analysis. Lipid biomarkers and their oxidation products were obtained after reduction with $\mathrm{NaBH}_{4}$ and subsequent saponification. All post-irradiation manipulations were conducted using foil-covered glassware to avoid photochemical artefacts. It is well known that metal ions can induce homolytic cleavage of hydroperoxides, and consequently promote free radical oxidation during procedures involving hot saponification (Pokorny, 1987). The preliminary reduction of the hydroperoxides ensured that such free radical oxidation artefacts were avoided during the alkaline hydrolysis step. Due to the use of $\mathrm{NaBH}_{4}$-reduction during the treatment, it was not possible to distinguish hydroperoxides from their ketonic and alcoholic degradation products. Note that cis-vaccenic acid oxidation products were obtained from the measurement of two groups of six isomeric hydroxyacids resulting from $\mathrm{NaBH}_{4}$ reduction of the corresponding hydroperoxyacids, i.e., 11-hydroxyoctadec-trans-12-enoic, 12-hydroxyoctadec-trans-10enoic, 13-hydroxyoctadec-trans-11-enoic, 13-hydroxyoctadec-cis-11enoic, 10-hydroxyoctadec-trans-11-enoic, and 10-hydroxyoctadec-cis11-enoic acids for cis-vaccenic acid (Marchand and Rontani, 2001). Photoproducts of palmitoleic acid $\left(C_{16: 1 \Delta 9}\right)$, which is also present in several bacteria (Blumer et al., 1969; Keweloh and Heipieper, 1996; Rontani et al., 2003), were also produced during the experiments. However, due to the lack of specificity of this acid (production by several phytoplanktonic species; Viso and Marty, 1993), its photoproducts were not further investigated.

\subsubsection{Reduction of hydroperoxides}

The hydroperoxides were reduced to alcohols in $\mathrm{MeOH}(25 \mathrm{~mL})$ by adding excess $\mathrm{NaBH}_{4}$ (10 mg per sample) using manual stirring (30 min at $20^{\circ} \mathrm{C}$ ) (Marchand and Rontani, 2003). During this treatment, ketones are also reduced to their corresponding alcohols and the possibility of some ester cleavage cannot be totally excluded.

\subsubsection{Alkaline hydrolysis}

Saponification was carried out on reduced samples (Marchand and Rontani, 2001; Marchand et al., 2005). After $\mathrm{NaBH}_{4}$ reduction, $25 \mathrm{~mL}$ of water and $2.8 \mathrm{~g}$ of potassium hydroxide were added and the mixture was directly saponified by refluxing for $2 \mathrm{~h}$. The aqueous phase was then acidified with $\mathrm{HCl}$ (final $\mathrm{pH}=1$ ) and subsequently extracted three times with dichloromethane (DCM). The combined DCM extracts 
were dried over anhydrous $\mathrm{Na}_{2} \mathrm{SO}_{4}$, filtered and concentrated by rotary evaporation at $40{ }^{\circ} \mathrm{C}$ to give the saponified fraction.

\subsubsection{Derivatization}

The residues were taken up in $300 \mu \mathrm{L}$ of a pyridine and bis(trimethylsilyl)trifluoroacetamide (BSTFA, Supelco, Bellefonte, PA, USA) mixture $(2: 1, \mathrm{v} / \mathrm{v})$ and silylated at $50{ }^{\circ} \mathrm{C}$ for $1 \mathrm{~h}$ (Pierce, 1982 ). After evaporation to dryness under nitrogen, the residues were taken up in a suitable volume of a mixture $(1: 1, v / v)$ of ethyl acetate and BSTFA (to avoid desilylation of easily silylated compounds) and analysed by gas chromatography-electron impact mass spectrometry (GC-EIMS).

2.7. Identification and quantification of lipid biomarkers and their degradation products by gas chromatography-electron impact mass spectrometry (GC-EIMS)

Analyses were carried out with an Agilent 7890A gas chromatograph connected to an Agilent 7000B triple quadrupole mass spectrometer working in electron impact (EI) mode. The following operating conditions were employed: $30 \mathrm{~m} \times 0.25 \mathrm{~mm}$ (i.d.) fused silica capillary column coated with HP-5MS (Agilent; film thickness: $0.25 \mu \mathrm{m}$ ); oven temperature programmed from 70 to $130{ }^{\circ} \mathrm{C}$ at $20^{\circ} \mathrm{C} \mathrm{min}{ }^{-1}$, from 130 to $250{ }^{\circ} \mathrm{C}$ at $5{ }^{\circ} \mathrm{C} \mathrm{min}{ }^{-1}$ and then from 250 to $300{ }^{\circ} \mathrm{C}$ at $3^{\circ} \mathrm{C} \mathrm{min}^{-1}$; carrier gas (He), 1.1 bar; injector (pulsed splitless) temperature, $280^{\circ} \mathrm{C}$; electron energy, $70 \mathrm{eV}$; source temperature, $230^{\circ} \mathrm{C}$; quadrupole 1 temperature, $150{ }^{\circ} \mathrm{C}$; quadrupole 2 temperature, $150{ }^{\circ} \mathrm{C}$; collision gas $\left(\mathrm{N}_{2}\right)$ flow, $1.5 \mathrm{~mL} \mathrm{~min}^{-1}$; quench gas (He) flow, $2.25 \mathrm{~mL} \mathrm{~min}{ }^{-1}$; collision energy, ranging from 4 to $15 \mathrm{eV}$ according to the selected transitions. Oxidation products of vaccenic acid were identified according to previously described procedures (Marchand and Rontani, 2001).

\section{Results and discussion}

\subsection{Singlet oxygen transfer efficiency}

Petit et al. (2013) previously showed that the photodegradation state of attached bacteria was well correlated with the degradation of chlorophyll $a$ in phytodetritus. If chlorophyll $a$ constitutes the main inducer of type II photosensitized oxidation in phytodetritus (Nelson, 1993), CDOM, which is produced increasingly during irradiation (Coelho et al., 2011; Cory et al., 2008, 2010; Dalrymple et al., 2010) can induce the production of singlet oxygen in the aqueous phase (Sandvik et al., 2000) and thus impact bacteria (Glaeser et al., 2010). Furthermore the initial degradation of carotenoids (which act as singlet oxygen quenchers) in senescent cells (Louda et al., 1998) in conjunction with the degradation of chlorophyll $a$ could amplify the photooxidative damages to bacteria. However, it may be noted that during a previous photodegradative experiment with non-axenic E. huxleyi (strain RCC1215) cells, the amounts of cis-vaccenic photoproducts in free bacteria (recovered in the filtrate after GF/F filtration) appeared to be less than the detection limit (i.e. $<4 \times 10^{-9} \mathrm{ng}$ cell $^{-1}$ ), while they reached $7 \times 10^{-7} \mathrm{ng} \mathrm{cell}^{-1}$ in attached bacteria (recovered on the GF/F filters) (Petit et al., 2013). Probably due to: (i) the higher diffusive distance in lipophilic membranes than in water (Suwa et al. 1977) and (ii) the high concentrations of sensitizer (chlorophyll) in chloroplasts, the transfer of singlet oxygen is thus much more efficient from phytodetritus to attached bacteria than from water to free bacteria.

Singlet oxygen-mediated photooxidation of monounsaturated fatty acids leads to the formation of hydroperoxides at each carbon of the original double bond (Frimer, 1979). Thus, photooxidation of cis-vaccenic acid in attached bacteria (Fig. 2) produces a mixture of 11- and 12-hydroperoxides with an allylic trans-double bond (Frankel, 1998), affording 13-trans and 10-trans hydroperoxides respectively, after stereoselective radical allylic rearrangement (Porter et al., 1995).
In contrast, free radical oxidation processes primarily involve allylic hydrogen abstraction and yield mixtures of six cis and trans isomeric allylic hydroperoxides (Frankel, 1998; Porter et al., 1995). Consequently the efficiency of the transfer of ${ }^{1} \mathrm{O}_{2}$ (Transfer Efficiency, $\mathrm{TE}^{1} \mathrm{O}_{2}$ ) from phytodetritus to attached bacteria is expressed according to Eq. (1), as the ratio of the sum of 11-trans, 12-trans, 13-trans and 10-trans hydroperoxides (after subtraction of the amounts of these compounds arising from autoxidation processes) versus the amount of photodegraded chlorophyll $a$ which is linked to the amount of singlet oxygen produced and is calculated as the concentration of degraded chlorophyll $a$ during light exposure (corresponding to photo- and biodegradation) minus the degraded chlorophyll $a$ in the control (corresponding to biodegradation). It may be noted that biodegraded chlorophyll $a$ concentrations in the control samples (unirradiated samples) were negligible compared to irradiated samples.

$\mathrm{TE}_{1} \mathrm{O}_{2}=\frac{[\text { cis-vaccenic acid photoproducts }]}{[\text { photodegraded chlorophyll } a]}$.

The results (Fig. 3) showed that the $\mathrm{TE}_{\mathrm{O}_{2}}$ for the diatoms Navicula cf. jeffreyi strain CS513 and Skeletonema cf. costatum strain RCC70 reached a maximum of 0.06 and 0.10 respectively (average $\mathrm{TE}_{\mathrm{O}_{2}}$ of $0.00 \pm 0.04$ for $15,390 \mathrm{~kJ} \mathrm{~m}^{-2}$ of PAR + UV irradiations received and $0.08 \pm 0.02$ for $14,400 \mathrm{~kJ} \mathrm{~m}^{-2}$ respectively. Averages were calculated on the 5 samples of each photodegradation experiment). The $\mathrm{TE}_{\mathrm{O}_{2}}$ of $E$. huxleyi strain RCC1215 reached a maximum of 0.87 and decreased slightly to 0.54 while the $\mathrm{TE}_{1} \mathrm{O}_{2}$ of $D$. tertiolecta strain RCC6 reached a maximum of 0.53 and decreased strongly to 0.10 . The lowest $\mathrm{TE}_{1} \mathrm{O}_{2}$ values observed in the case of senescent Skeletonema cf. costatum and Navicula cf. jeffreyi type cells strongly suggest a limitation of ${ }^{1} \mathrm{O}_{2}$ transfer from senescent phytoplankton cells to the attached bacteria, which could be explained by the polar properties of the silica matrix (charged mineral surface). Although the carbonaceous matrix constituted by coccoliths is also a charged mineral surface, the highest $\mathrm{TE}_{1} \mathrm{O}_{2}$ was observed in the case of E. huxleyi. This observation could be explained by the release of coccoliths upon cell senescence (Moore et al., 2012; Paasche, 2002) allowing the transfer of ${ }^{1} \mathrm{O}_{2}$. This assumption is well supported by the high $\mathrm{TE}_{1} \mathrm{O}_{2}$ also observed in the case of $D$. tertiolecta. Indeed, this unicellular, eukaryotic and photosynthetic microorganism lacks a rigid cell wall, so the cellular contents are enclosed by an elastic plasma membrane (Ben-Amotz and Avron, 1980).

The limitation of ${ }^{1} \mathrm{O}_{2}$ transfer in the marine diatom frustules may be attributed not only to the polar character of silica itself, but also to the presence of mycosporine-like amino acids (MAAs) in diatom frustules (Ingalls et al., 2010). Indeed, these compounds protect cells from reactive oxygen species (i.e. ${ }^{1} \mathrm{O}_{2}$, superoxide anions, hydroperoxyl radicals and hydroxyl radicals) (Suh et al., 2003) and can also be found in D. tertiolecta (as mycosporine-glycine; Carreto and Carignan, 2011). However, the induction of mycosporine-glycine is produced by irradiance in the UVB range (maximum absorbance at $310 \mathrm{~nm}$; Whitehead and Vernet, 2000) and due to the use of Pyrex materials during our experiments (which exclude UVB transmission) this hypothesis seems very unlikely. The decrease of $\mathrm{TE}^{1} \mathrm{O}_{2}$ observed at the end of irradiation in the case of E. huxleyi and D. tertiolecta (Fig. 3) was attributed to homolytic cleavage of hydroperoxides (Fig. 2) by UV radiation (Horspool and Armesto, 1992) and/or metal ions (Pokorny, 1987; Schaich, 1992).

In the case of $D$. tertiolecta, it is very likely that $\mathrm{HgCl}_{2}$ (used in order to induce cell death) may have strongly catalysed homolytic cleavage of photochemically produced hydroperoxides. Indeed, metal ions undergoing one-electron transfers such as mercury, cobalt, iron, copper, manganese, magnesium and vanadium appear to be very active catalysts of hydroperoxide homolysis. This assumption is supported by: (i) the strong decrease of the $\mathrm{TE}_{1} \mathrm{O}_{2}$ observed (Fig. 3) and (ii) the high proportion (Fig. 4) of 13-hydroxyoctadec-cis-11-enoic (13-cis hydroperoxide) and 10-hydroxyoctadec-cis-11-enoic acids (10-cis hydroperoxide), which are specific tracers of autoxidative processes 


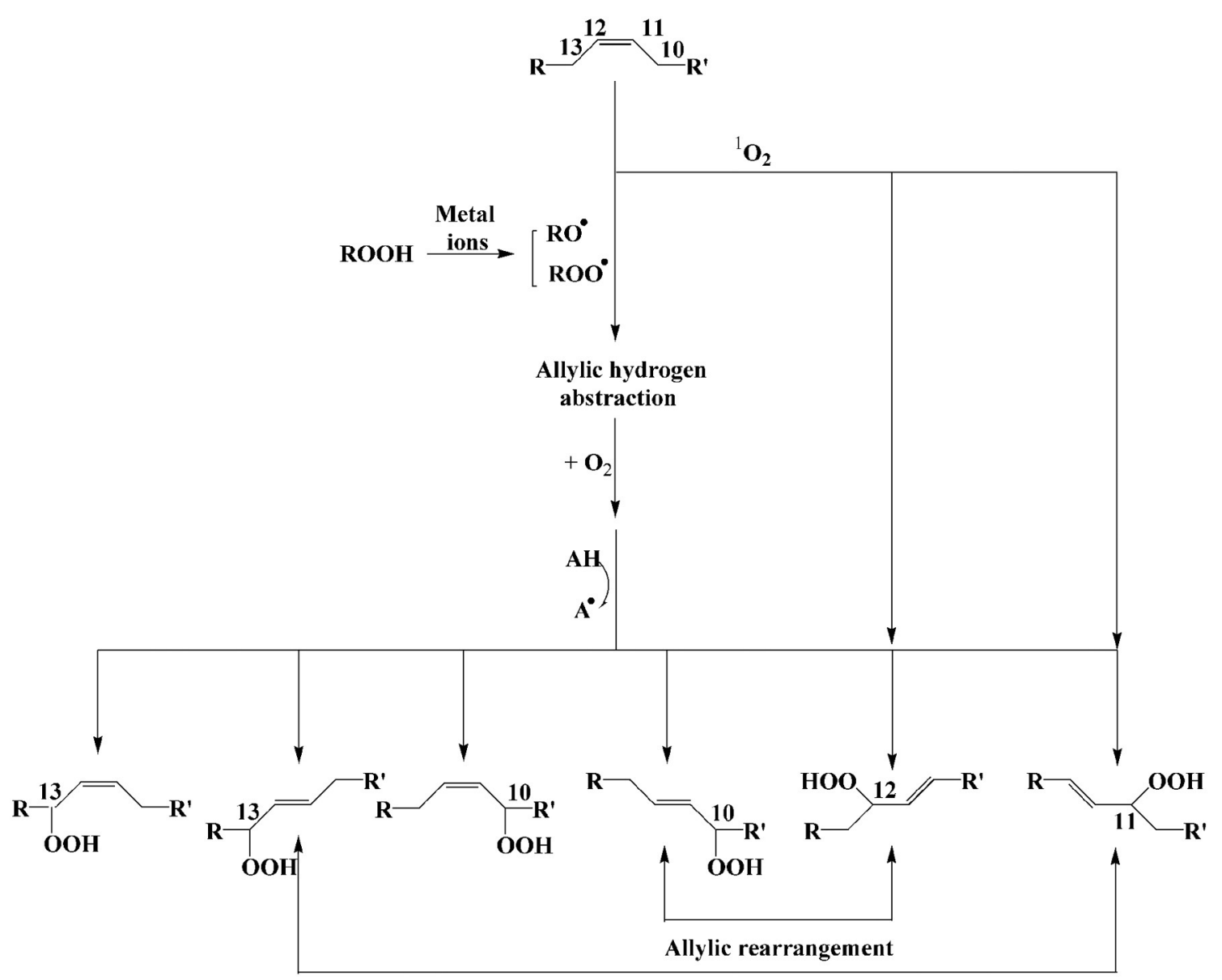

Allylic rearrangement

$$
\begin{aligned}
& \mathbf{R}=-\left(\mathrm{CH}_{2}\right)_{4}-\mathrm{CH}_{3} \\
& \mathbf{R}^{\prime}=-\left(\mathrm{CH}_{2}\right)_{8}-\mathrm{COOH}
\end{aligned}
$$

$\mathbf{A H}=$ Hydrogen donors

Fig. 2. Hydroperoxides resulting from autoxidation and ${ }^{1} \mathrm{O}_{2}$-mediated photooxidation of octadec-11-enoic acid in attached bacteria.

(Marchand and Rontani, 2001). Comparison of the results obtained with this strain with those of the other algae is not straightforward. Indeed, mercuric chloride would have also induced the death of bacteria and favoured the involvement of autoxidative processes. However, the results obtained at the beginning of irradiation (i.e. when autoxidation was not effective), clearly show that TE observed in the case of naked phytoplanktonic cells are higher than for the diatoms.

It is important to note that even when $\mathrm{HgCl}_{2}$ is absent, homolytic cleavage of hydroperoxides resulting from the reaction of ${ }^{1} \mathrm{O}_{2}$ with unsaturated components of the outer lipopolysaccharide membrane of Gram-negative bacteria (the dominant bacteria in the ocean) leads to the formation of reactive secondary products, such as peroxyl radicals, which may in turn accelerate cell death (Dahl et al., 1989) and regenerate ${ }^{1} \mathrm{O}_{2}$ by the Russell mechanism (Miyamoto et al., 2003). Consequently, both autoxidation and photooxidation appear to be strongly favoured during the abiotic degradation of bacterial organic matter.

\subsection{Effect of biogenic silica concentration on the transfer of singlet oxygen}

\subsubsection{Growth synchronisation and biogenic silica content}

Results from flow cytometry indicated that during the first $7 \mathrm{~h}$ after the reintroduction of $\mathrm{dSi}$ in the medium, the cell cycle of
T. weissflogii was not restarted and all cells were in G2 + M phase (gap time + mitosis, before cell division; Figs. 5 and 6). After two days of growth, synchrony was not fully reached and two pools of cells were detected including one in the G1 phase (gap time, cell growth and expansion) and the other in the $\mathrm{G} 2+\mathrm{M}$ phase (Fig. 6). This result indicates a clear synchrony at the beginning of the growth period which was lost after two days and confirms that the growth of synchronised diatoms in batch culture is not maintained after three complete cell cycles. Nevertheless, this methodology was useful in reproducing environmental conditions experienced by diatom cells in the water column and enabled us to vary biogenic silica content per cell. The non-homogenous cell population after two days of growth and the reduction of the cell size during growth due to asexual reproduction (Fig. 5) could bias the estimation of the bSi content per cell and lead to a different average bSi content per cell due to different cell size. However, this cell size reduction was very weak during the 21 days of growth as indicated by flow cytometry results (data not shown) leading to an accurate estimation of the bSi content per cell.

The content of bSi of T. weissflogii (Fig. 7) varied considerably over the time course experiment as previously observed by Vrieling et al. (1999) during growth of a culture of T. weissflogii under controlled conditions. Just after the inoculation with $\mathrm{NaSiO}_{3}$ solution, the bSi 


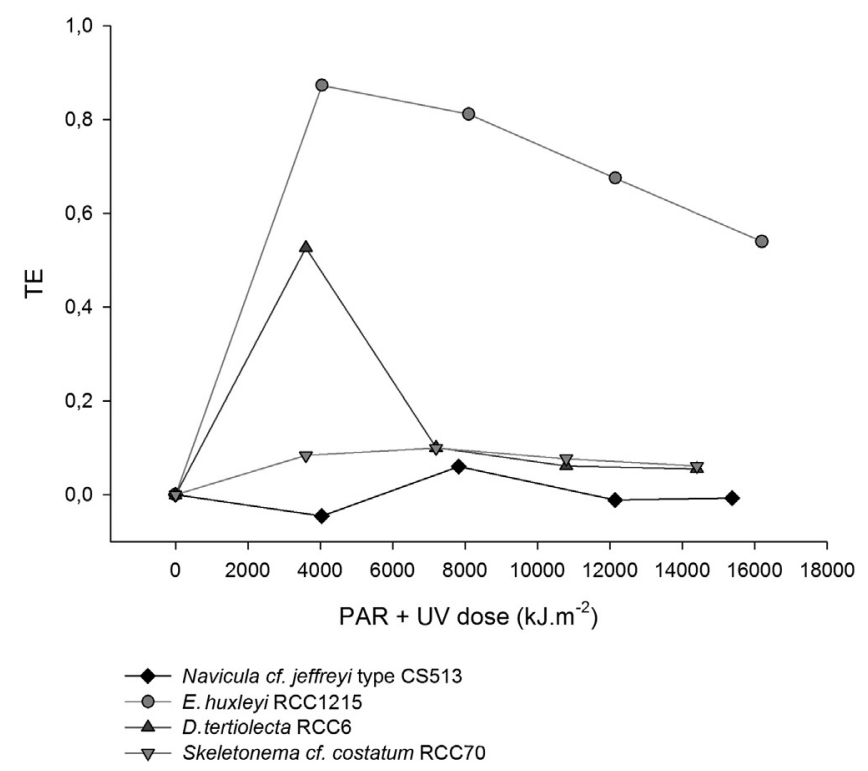

Fig. 3. Singlet oxygen transfer efficiency $\left(\mathrm{TE}^{\mathrm{O}_{2}}\right)$ during PAR $+\mathrm{UV}$ irradiation $\left(\mathrm{kJ} \mathrm{m}^{-2}\right)$ of senescent cells of Navicula cf. jeffreyi type (silica matrix), E. huxleyi (carbonaceous matrix), D. tertiolecta (no matrix) and Skeletonema cf. costatum (silica matrix).

concentration increased from $24.0 \pm 2.3 \mu \mathrm{mol} \mathrm{L}^{-1}$ to $146.2 \pm$ $1.5 \mu \mathrm{mol} \mathrm{L}{ }^{-1}$ in 20 days, while the concentration of bSi per cell significantly decreased (ANOVA and Tukey HSD test, $\mathrm{p}<0.05$ ) from $2.0 \pm$ $0.2 \mathrm{pmol} \mathrm{cell}^{-1}$ to $0.5 \pm 0.0 \mathrm{pmol} \mathrm{cell}^{-1}$.

\subsubsection{Effect of the biogenic silica concentration on singlet oxygen transfer}

We could not quantify free and attached bacteria during this study, however the high values of the ratio cis-vaccenic acid (bacterial tracer)/palmitoleic acid (main fatty acid of $T$. weissflogii) observed after $\mathrm{GF} / \mathrm{F}$ filtration (close to 0.30 ) confirm the presence of high amounts of bacteria attached to diatom cells. Interestingly, it may be also noted that the amounts of cis-vaccenic acid did not change significantly during the growth of $T$. weissflogii, attesting to a relative stability of the proportion of attached bacteria.

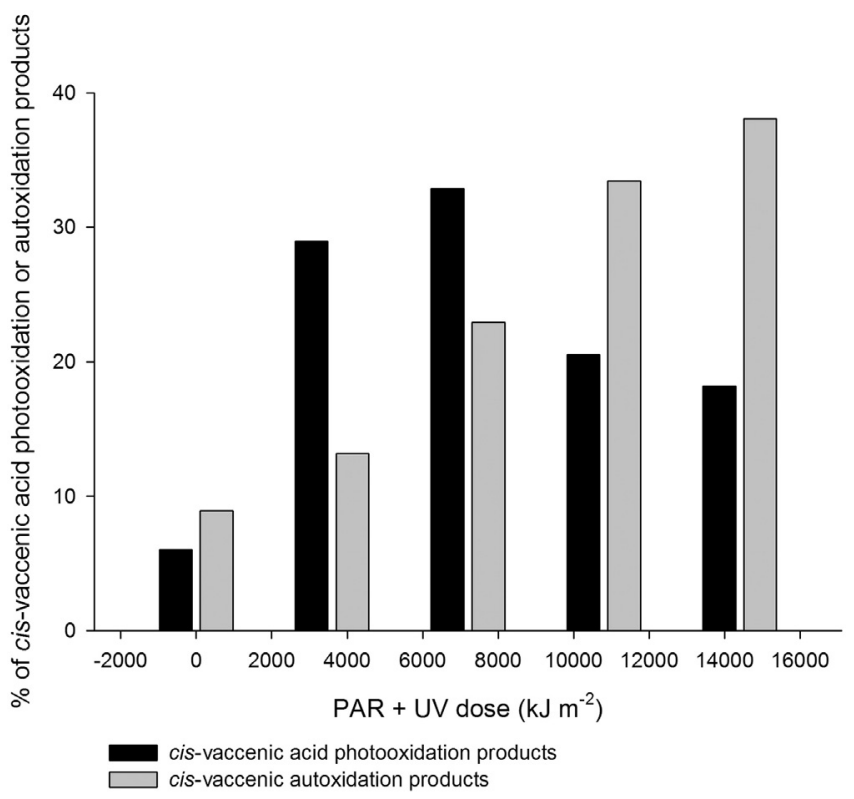

Fig. 4. Percentage of cis-vaccenic photooxidation and autoxidation products of D. tertiolecta produced during the photodegradation experiment.
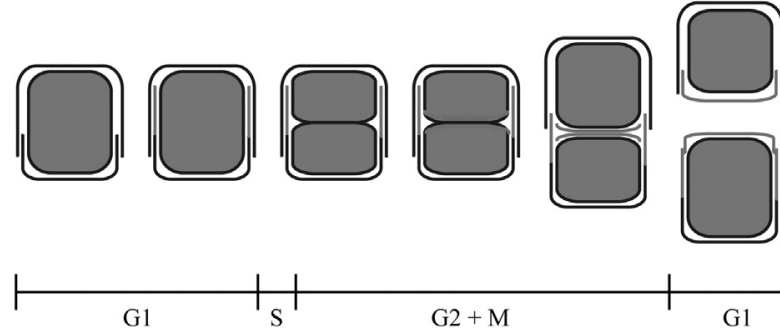

G1

$\mathrm{G} 2+\mathrm{M}$

G1

Fig. 5. Asexual reproduction of diatom cells (redrawn from Hildebrand et al., 2007). Different stages in the cell cycle are represented: G1 phase = gap time, cell growth and expansion, $\mathrm{S}$ phase $=$ two daughter-cell protoplasts in the mother cell, and G2 $+\mathrm{M}$ phase $=$ gap time + mitosis, before cell division.

We assume that chlorophyll $a$ is the main source of ${ }^{1} \mathrm{O}_{2}$ responsible for photooxidation in our experiment, so data were normalized to the average content of chlorophyll $a$ per cell of $T$. weissflogii. The percentage of photooxidation products of cis-vaccenic acid (bacterial marker) adjusted to the concentration of chlorophyll $a$ per T. weissflogii cell decreased from $10.0 \pm 0.3 \%$ to $0.8 \pm 0.4 \%$ (and from $1.3 \%$ to $0.0 \%$ for the control), while bSi concentration increased from $0.5 \pm 0.0$ to $2.0 \pm 0.2 \mathrm{pmol} \mathrm{cell}^{-1}$ (Fig. 8). The percentage of cis-vaccenic acid photooxidation thus appears to be inversely correlated with the biogenic silica concentration. Note that since the lowest biogenic silica values correspond to oldest cells, there is a possibility that the increase of cis-vaccenic acid oxidation could simply be due to the increasing senescent state of the cells. However, we previously showed that the oxidation of the bacterial cis-vaccenic acid is well correlated with the photodegradation state of phytoplanktonic chlorophyll (Petit et al., 2013). The increase in chlorophyll/cell values observed between the beginning and the end of the growth of $T$. weissflogii (from $0.910^{-6}$ to $1.910^{-6} \mu \mathrm{g}$ chlorophyll $a$ cell $^{-1}$ ) clearly shows that cells exhibiting the lowest silica content were not in an advanced stage of senescence. This result confirms that bSi may efficiently inhibit the transfer of ${ }^{1} \mathrm{O}_{2}$ from senescent diatom cells to their attached bacteria. In the future, it will be interesting to check the effects of TEP on this transfer. Indeed, due to the polar character of polysaccharides, such compounds could also contribute to the limitation of ${ }^{1} \mathrm{O}_{2}$ transfer to attached bacteria in fast sinking aggregates.

Interestingly the relationship between the \% of cis-vaccenic acid photooxidation (adjusted to the concentration of chlorophyll $a$ per T. weissflogii cell) and the bSi per cell is nonlinear (Fig. 8). This suggests the existence of a bSi threshold (close to $0.8 \mathrm{pmol}^{\text {cell }}{ }^{-1}$ ) during

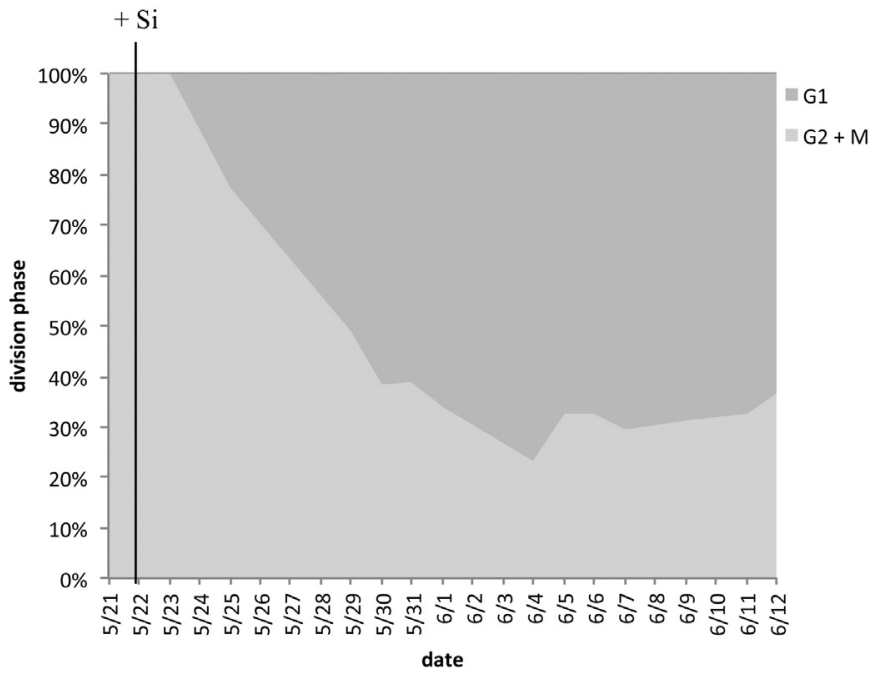

Fig. 6. Percentage composition of the G1 and G2 + M division phases during the growth of $T$. weissflogii. 


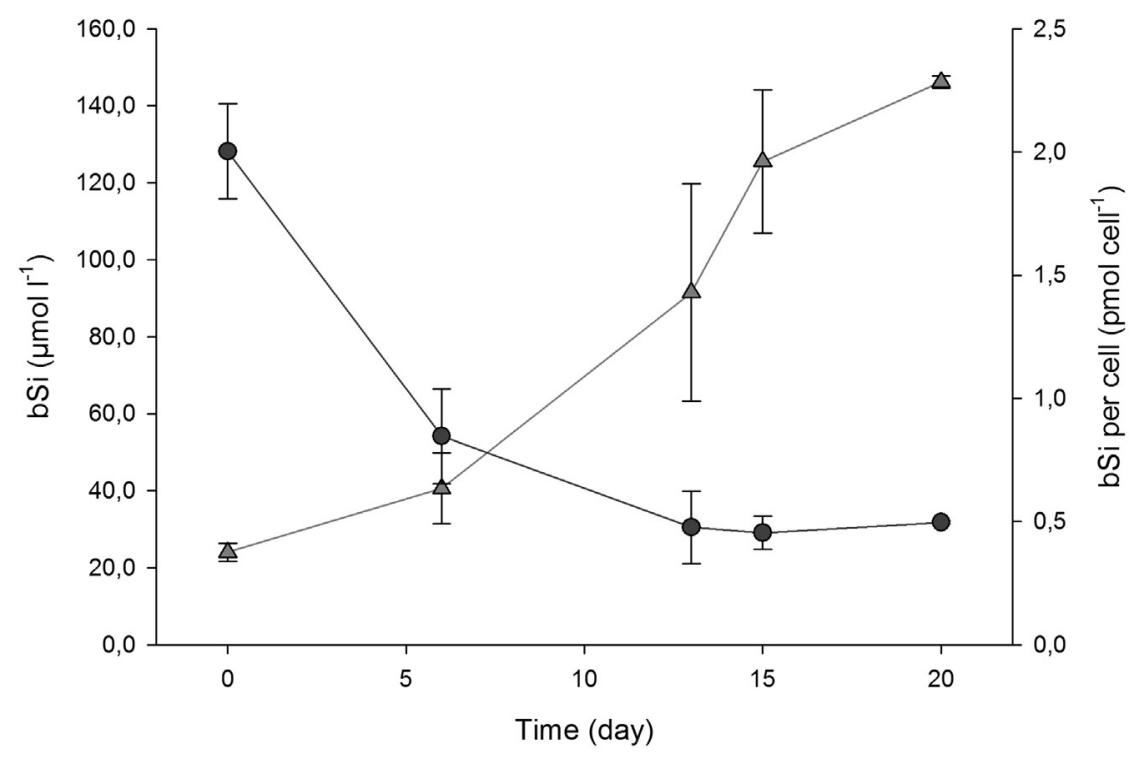

$\triangle \mathrm{bSi}$

bSi per cell

Fig. 7. Evolution of the biogenic silica (bSi) concentration $\left(\mu \mathrm{mol} \mathrm{L}^{-1}\right)$ and $\mathrm{bSi}$ content per cell (pmol cell ${ }^{-1}$ ) during the growth of $T$. weissflogii.

inhibition of ${ }^{1} \mathrm{O}_{2}$ transfer. Furthermore, we note that the hypothesis of silica matrix inhibition of singlet oxygen transfer is well supported by the low percentages of cis-vaccenic photooxidation products (relative to the parent compound) observed during the time course experiment (from $0.8 \% \pm 0.4$ to $1.7 \% \pm 0.6$ ) (Table 1 ).

\section{Conclusions}

Photodegradation processes were investigated in different non-axenic senescent cultures of 4 phytoplankton species. Specific attention was devoted to the effect of the silica matrix and carbonaceous matrix on the transfer of ${ }^{1} \mathrm{O}_{2}$ from the phytodetritus to the attached bacteria. Cis-vaccenic acid (a specific and abundant component of Gram-negative bacteria) was employed to monitor the effects of the photodegradation processes in bacteria.

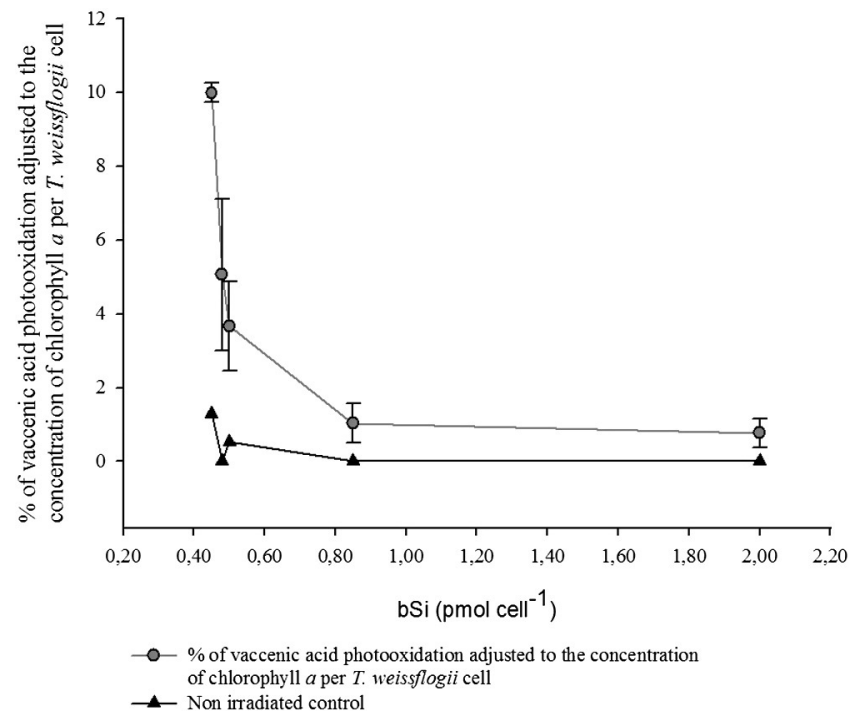

Fig. 8. Evolution of the percentage of cis-vaccenic acid photooxidation products adjusted to concentration of chlorophyll a per T. weissflogii cell according to the concentration of biogenic silica (pmol cell $\left.{ }^{-1}\right)$.
The first experiment showed that the silica matrix strongly inhibits the transfer of ${ }^{1} \mathrm{O}_{2}$ from phytodetritus to attached bacteria compared to a carbonaceous matrix. The strong limitation of ${ }^{1} \mathrm{O}_{2}$ transfer by the silica matrix could be attributed either to the polar character of the charged mineral surface of the frustule, which can decrease the lifetime of ${ }^{1} \mathrm{O}_{2}$, and/or to the presence of mycosporine-like amino acids in the frustule of diatoms, which can act as a quencher of ${ }^{1} \mathrm{O}_{2}$. In contrast, the shedding of coccoliths during the senescence of $E$. huxleyi cells may allow an efficient ${ }^{1} \mathrm{O}_{2}$ transfer to occur.

The second experiment supported the hypothesis that a silica matrix inhibited ${ }^{1} \mathrm{O}_{2}$ transfer. Indeed, we could clearly show that the inhibition of the transfer of ${ }^{1} \mathrm{O}_{2}$ to the attached bacteria is directly linked to the concentration of biogenic silica concentration in diatoms cells and could thus favour biodegradation of phytodetritus resulting from these organisms. These results provide support for the hypothesis proposed by Rontani et al. (2011), who explained the unexpectedly intense biotic degradation of sinking particulate organic particles previously observed in the equatorial Pacific Ocean (Sheridan et al., 2002). Indeed, in this zone significant photodegradation and autoxidation of lipids associated with both suspended and sinking particles was observed but the biodegradation was more intense in sinking particles than in suspended particles. These authors thus attributed this degradation to the abundance of charged mineral surfaces such as siliceous diatom frustules or carbonaceous coccoliths in sinking particles, whose presence reduces the lifetime of ${ }^{1} \mathrm{O}_{2}$ and allows for enhanced

Table 1

Percentage of cis-vaccenic acid photooxidation products in dead samples of a non-axenic culture of $T$. weissflogii over the time course irradiation experiment.

\begin{tabular}{lll}
\hline Samples & $\begin{array}{l}\text { Irradiation dose } \\
\text { received }\left(\mathrm{kJ} \mathrm{m}^{-2}\right)\end{array}$ & $\begin{array}{l}\text { \% cis-vaccenic photooxidation } \\
\text { products }\end{array}$ \\
\hline T1 & 7200 & $0.8 \pm 0.4$ \\
T2 & 7200 & $0.4 \pm 0.2$ \\
T3 & 7200 & $3.7 \pm 1.5$ \\
T4 & 7200 & $4.8 \pm 0.1$ \\
T5 & 7200 & $1.7 \pm 0.6$ \\
T1 control & 0 & 0.0 \\
T2 control & 0 & 0.0 \\
T3 control & 0 & 0.0 \\
T4 control & 0 & 0.6 \\
T5 control & 0 & 0.2 \\
\hline
\end{tabular}


bacterial growth and biodegradation in sinking particles compared to suspended particles. Our results are in good agreement with some previous observations made by Gowing and Silver (1983) and Karl and Knauer (1984) in the northeast Pacific Ocean that sinking particles (often composed of aggregated diatoms) contain a much more active bacterial community than suspended particles.

It is interesting to note that although the irradiance employed during this work $\left(500 \mathrm{~W} \mathrm{~m}^{-2}\right)$ corresponds to surface conditions in summer in the western Mediterranean Sea, this does not imply that photooxidation processes are limited to high irradiances. Indeed, it was recently observed in the Arctic that, despite the very low irradiance measured, diatoms were strongly photooxidized at the bottom of sea ice (Rontani et al., 2014). It is very important to understand that in phytoplanktonic cells this is the same energy which is employed during photosynthesis and photooxidation. Consequently, when there is a sufficient irradiance for the growth of phytoplankton (as at the deep chlorophyll maximum), this is sufficient for its photodegradation. In the marine medium, the solar light spectrum changes with depth, the first wavelengths absorbed are the longer, less energetic wavelengths in the red region of the spectrum; the blue wavelengths responsible for one of the two absorption maxima of chlorophyll (at 430 and $662 \mathrm{~nm}$ ) penetrate the farthest into the water allowing chlorophyll-induced photosensitized oxidation processes to act throughout the euphotic layer. Recent results (Amiraux, R., unpublished results), which are still under investigation, seem to indicate that low irradiances and low temperatures both favour photodegradation of phytoplanktonic components. This paradoxical effect could be attributed to a slowing down of the rates of photodegradation of chlorophyll and/or of the diffusion of singlet oxygen in membranes increasing the efficiency of the photosensitizing processes.

It is now clear that it is not possible to discuss the fate of phytodetritus simply in terms of biodegradation. Indeed, abiotic processes (photooxidation and autoxidation) also act intensively on this material (Rontani et al., 2012). A precise estimation of the balance between degradation and preservation of organic material during sedimentation needs not only to take into account the relative importance of each of these processes but also to elucidate all of their interactions.

\section{Acknowledgements}

This work was performed within the framework of the transverse axis DEBAT (DEgradation Biotique et AbioTique de la matière organique en milieu marin: processus et interactions) of the MIO and funded by research grants from the PHOTOMED (MERMEX-WP4/MISTRALS) and TRANSPHYTOBAC (EC2CO-Microbien) CNRS research projects. This study is a contribution to the international IMBER and SOLAS projects. Flow cytometry analyses and sorting were realized using the PRECYM flow cytometry platform (http://precym.com.univ-mrs.fr). We wish to thank Nicole Garcia for the analysis of chlorophyll $a$. The PhD scholarship was provided by Aix Marseille University (EDSV 251) and the Ministry of Research and Technology. We thank Drs. Susan Blackburn and Ian Jameson for providing cultured material from the CSIRO Collection of Living Microalgae (now Australian National Algae Culture Collection). Thanks are due to two anonymous reviewers for their useful and constructive comments.

\section{References}

Aminot, A., Kérouel, R., 2004. Mesures des concentrations en carbone, azote et phosphore organiques particulaires. Hydrologie Des Écosystèmes Marins. Paramètres et Analyses. IFREMER, Plouzané, France, pp. 194-214.

Baier, J., Maier, M., Engl, R., Landthaler, M., Bäumler, W., 2005. Time-resolved investigations of singlet oxygen luminescence in water, in phosphatidylcholine and in aqueous suspensions of phosphatidylcholine on HT29 cells. J. Phys. Chem. B 109, 3041-3046. http://dx.doi.org/10.1021/jp0455531.
Ben-Amotz, A, Avron, M. 1980. Osmoregulation in the halophilic algae Dunaliella and Asteromonas. In: Rains, D.W., Valentine, R.C., Hollaender, A. (Eds.), Genetic Engineering of Osmoregulation SE - 8. Basic Life Sciences, Springer USA, pp. 91-99 http://dx.doi.org/10.1007/978-1-4684-3725-6_8.

Ben-Amotz, A., Avron, M., 1992. Dunaliella: Physiology, Biochemistry, and Biotechnology. CRC Press.

Bidle, K.D., Azam, F., 2001. Bacterial control of silicon regeneration from diatom detritus: significance of bacterial ectohydrolases and species identity. Limnol. Oceanogr. 46 1606-1623. http://dx.doi.org/10.4319/lo.2001.46.7.1606.

Blumer, M., Chase, T., Watson, S., 1969. Fatty acids in the lipids of marine and terrestrial nitrifying bacteria. J. Bacteriol. 99, 366-370.

Boyd, P.W., Trull, T.W., 2006. Understanding the export of biogenic particles in oceanic waters: is there consensus? Prog. Oceanogr. 72, 276-312. http://dx.doi.org/10.1016/ j.pocean.2006.10.007.

Brown, C.W., Yoder, J.A., 1994. Coccolithophorid blooms in the global ocean. J. Geophys. Res. 99, 7467-7482

Carreto, J.I., Carignan, M.O., 2011. Mycosporine-like amino acids: relevant secondary metabolites. Chemical and ecological aspects. Mar. Drugs 9, 387-446. http://dx.doi org/10.3390/md9030387.

Christodoulou, S., Marty, J.-C., Miquel, J.-C., Volkman, J.K., Rontani, J.-F., 2009. Use of lipids and their degradation products as biomarkers for carbon cycling in the northwestern Mediterranean Sea. Mar. Chem. 113, 25-40.

Christodoulou, S., Joux, F., Marty, J.-C., Sempéré, R., Rontani, J.-F., 2010. Comparative study of UV and visible light induced degradation of lipids in non-axenic senescent cells of Emiliania huxleyi. Mar. Chem. 119, 139-152. http://dx.doi.org/10.1016/j.marchem. 2010.01.007.

Coelho, C., Guyot, G., ter Halle, A., Cavani, L., Ciavatta, C., Richard, C., 2011. Photoreactivity of humic substances: relationship between fluorescence and singlet oxygen production. Environ. Chem. Lett. 9, 447-451. http://dx.doi.org/10.1007/s10311010-0301-3.

Cory, R.M., Cotner, J.B., McNeill, K., 2008. Quantifying interactions between singlet oxygen and aquatic fulvic acids. Environ. Sci. Technol. 43, 718-723. http://dx.doi.org/10. 1021/es801847g.

Cory, R.M., McNeill, K., Cotner, J.P., Amado, A., Purcell, J.M., Marshall, A.G., 2010. Singlet oxygen in the coupled photochemical and biochemical oxidation of dissolved organic matter. Environ. Sci. Technol. 44, 3683-3689. http://dx.doi.org/10.1021/es902989y.

Dahl, T.A., Midden, W.R., Hartman, P.E., 1989. Comparison of killing of Gram-negative and Gram-positive bacteria by pure singlet oxygen. J. Bacteriol. 171, 2188-2194.

Dalrymple, R.M., Carfagno, A.K., Sharpless, C.M., 2010. Correlations between dissolved organic matter optical properties and quantum yields of singlet oxygen and hydrogen peroxide. Environ. Sci. Technol. 44, 5824-5829. http://dx.doi.org/10. 1021/es101005u.

Decho, A.W., 1990. Microbial exopolymer secretions in ocean environments: their role(s) in food webs and marine processes. Oceanogr. Mar. Biol. Annu. Rev. 28, 73-153.

Foote, C.S., 1976. Photosensitized oxidation and singlet oxygen: consequences in biological systems. Free Radicals in Biology vol. 2. Academic Press, New York.

Frankel, E.N., 1998. Lipid Oxidation. The Oily Press, Dundee.

Frimer, A.A., 1979. The reaction of singlet oxygen with olefins: the question of mechanism. Chem. Rev. 79, 359-387. http://dx.doi.org/10.1021/cr60321a001.

Garcia-Pichel, F., 1994. A model for internal self-shading in planktonic organisms and its implications for the usefulness of ultraviolet sunscreens. Limnol. Oceanogr. 39, 1704-1717.

Gärdes, A., Iversen, M.H., Grossart, H.-P., Passow, U., Ullrich, M.S., 2011. Diatom-associated bacteria are required for aggregation of Thalassiosira weissflogii. ISME J. 5, 436-445. http://dx.doi.org/10.1038/ismej.2010.145.

Ghiglione, J.F., Mevel, G., Pujo-Pay, M., Lebaron, P., Goutx, M., 2007. Diel and seasonal variations in abundance, activity, and community structure of particle-attached and free-living bacteria in NW Mediterranean Sea. Microb. Ecol. 54, 217-231.

Glaeser, S.P., Grossart, H.-P., Glaeser, J., 2010. Singlet oxygen, a neglected but important environmental factor: short-term and long-term effects on bacterioplankton composition in a humic lake. Environ. Microbiol. 12, 3124-3136. http://dx.doi.org/ 10.1111/j.1462-2920.2010.02285.x.

Goutx, M., Wakeham, S.G. Lee, C., Duflos, M., 2007. Composition and degradation of marine particles with different settling velocities in the northwestern Mediterranean Sea. Limnol. Oceanogr. 52, 1645-1664.

Gowing, M., Silver, M., 1983. Origins and microenvironments of bacteria mediating fecal pellet decomposition in the sea. Mar. Biol. 16, 7-16.

Hildebrand, M., Frigeri, L.G., Davis, A.K., 2007. Synchronized growth of Thalassiosira pseudonana (Bacillariophyceae) provides novel insights into cell-wall synthesis processes in relation to the cell cycle 1. J. Phycol. 43, 730-740. http://dx.doi.org/10. 1111/j.1529-8817.2007.00361.x.

Holm-Hansen, O., Lorenzen, C.J., Holmes, R.W., Strickland, J.D.H., 1965. Fluorometric determination of chlorophyll. ICES J. Mar. Sci. 30, 3-15. http://dx.doi.org/10.1093/ icesjms/30.1.3.

Honjo, S., Okada, H., 1974. Community structure of coccolithophores in the photic layer of the mid-Pacific. Micropaleontology 20, 209-230.

Horspool, W.M., Armesto, D., 1992. Organic Photochemistry: A Comprehensive Treatment, Ellis Horwood Series in Physical Chemistry. Prentice Hall Chichester U. K.

Ingalls, A.E., Whitehead, K., Bridoux, M.C., 2010. Tinted windows: the presence of the UV absorbing compounds called mycosporine-like amino acids embedded in the frustules of marine diatoms. Geochim. Cosmochim. Acta 74, 104-115. http://dx.doi. org/10.1016/j.gca.2009.09.012

Karl, D.M., Knauer, G.A., 1984. Vertical distribution, transport, and exchange of carbon in the northeast Pacific Ocean: evidence for multiple zones of biological activity. Deep Sea Res. A. Oceanogr. Res. Pap. 31, 221-243.

Keweloh, H., Heipieper, H.-J., 1996. Trans unsaturated fatty acids in bacteria. Lipids 31 129-137. 
Kiørboe, T., Hansen, J.L.S., 1993. Phytoplankton aggregate formation: observations of patterns and mechanisms of cell sticking and the significance of exopolymeric material. J. Plankton Res. 15, 993-1018. http://dx.doi.org/10.1093/plankt/15.9.993.

Knox, J.P., Dodge, A.D., 1985. Singlet oxygen and plants. Phytochemistry 24, 889-896.

Louda, J.W., Li, J., Liu, L., Winfree, M.N., Baker, E.W., 1998. Chlorophyll-a degradation during cellular senescence and death. Org. Geochem. 29, 1233-1251. http://dx.doi. org/10.1016/S0146-6380(98)00186-7.

Malejl, A., Harris, R.P., 1993. Inhibition of copepod grazing by diatom exudates: a factor in the development of mucus aggregates? Mar. Ecol. Prog. Ser. 96, 33-42.

Marchand, D., Rontani, J.-F., 2001. Characterisation of photo-oxidation and autoxidation products of phytoplanktonic monounsaturated fatty acids in marine particulate matter and recent sediments. Org. Geochem. 32, 287-304.

Marchand, D., Rontani, J.-F., 2003. Visible light-induced oxidation of lipid components of purple sulfur bacteria: a significant process in microbial mats. Org. Geochem. 34, 61-79. http://dx.doi.org/10.1016/S0146-6380(02)00192-4

Marchand, D., Marty, J.-C., Miquel, J.-C., Rontani, J.-F., 2005. Lipids and their oxidation products as biomarkers for carbon cycling in the northwestern Mediterranean Sea: results from a sediment trap study. Mar. Chem. 95, 129-147.

Marker, A.F.H., 1972. The use of acetone and methanol in the estimation of chlorophyll in the presence of phaeophytin. Freshw. Biol. 2, 361-385. http://dx.doi.org/10.1111/j. 1365-2427.1972.tb00377.x.

Marlowe, I.T., Brassell, S.C., Eglinton, G., Green, J.C., 1990. Long-chain alkenones and alkyl alkenoates and the fossil coccolith record of marine sediments. Chem. Geol. 88, 349-375. http://dx.doi.org/10.1016/0009-2541(90)90098-R.

Miyamoto, S., Martinez, G.R., Medeiros, M.H.G., Di Mascio, P., 2003. Singlet molecular oxygen generated from lipid hydroperoxides by the Russell mechanism: studies using 18(0)-labeled linoleic acid hydroperoxide and monomol light emission measurements. J. Am. Chem. Soc. 125, 6172-6179. http://dx.doi.org/10.1021/ja029115o.

Moore, T.S., Dowell, M.D., Franz, B.A., 2012. Detection of coccolithophore blooms in ocean color satellite imagery: a generalized approach for use with multiple sensors. Remote Sens. Environ. 117, 249-263. http://dx.doi.org/10.1016/j.rse.2011.10.001.

Nelson, J.R., 1993. Rates and possible mechanism of light-dependent degradation of pigments in detritus derived from phytoplankton. J. Mar. Res. 51, 155-179. http:// dx.doi.org/10.1357/0022240933223837.

Nelson, D.M., Tréguer, P., Brzezinski, M.A., Leynaert, A., Quéguiner, B., 1995. Production and dissolution of biogenic silica in the ocean: revised global estimates, comparison with regional data and relationship to biogenic sedimentation. Glob. Biogeochem. Cycles 9, 359-372.

Ogilby, P.R., 2010. Singlet oxygen: there is indeed something new under the sun. Chem. Soc. Rev. 39, 3181-3209. http://dx.doi.org/10.1039/B926014P.

Okada, H., Honjo, S., 1973. The distribution of oceanic coccolithophorids in the Pacific. Deep-Sea Res. 20, 355-374. http://dx.doi.org/10.1016/0011-7471(73)90059-4.

Paasche, E., 2002. A review of the coccolithophorid Emiliania huxleyi (Prymnesiophyceae), with particular reference to growth, coccolith formation, and calcification-photosynthesis interactions. Phycologia 40, 503-529.

Petit, M., Sempéré, R., Vaultier, F., Rontani, J.-F., 2013. Photochemical production and behavior of hydroperoxyacids in heterotrophic bacteria attached to senescent phytoplanktonic cells. Int. J. Mol. Sci. 14, 11795-11815. http://dx.doi.org/10.3390/ ijms140611795.

Petit, M., Bonin, P., Amiraux, R., Michotey, V., Guasco, S., Armitano, J., Jourlin-Castelli, C., Vaultier, F., Méjean, V., Rontani, J.-F., 2015. Dynamic of bacterial communities attached to lightened phytodetritus. Environ. Sci. Pollut. Res. http://dx.doi.org/10. $1007 /$ s11356-015-4209-0 (in press).

Pierce, A.E., 1982. Silylation of Organic Compounds. Pierce Chemical Co., Rockford, Illinois.

Pokorny, J., 1987. Major factors affecting the autoxidation of lipids. Autoxidation of Unsaturated Lipids. Academic Press, London.

Porter, N.A., Caldwell, S.E., Mills, K.A., 1995. Mechanisms of free radical oxidation of unsaturated lipids. Lipids 30, 277-290. http://dx.doi.org/10.1007/bf02536034.

Ragueneau, O., Tréguer, P., 1994. Determination of biogenic silica in coastal waters: applicability and limits of the alkaline digestion method. Mar. Chem. 45, 43-51. http://dx.doi.org/10.1016/0304-4203(94)90090-6.

Richardson, K., Beardall, J., Raven, J.A., 1983. Adaptation of unicellular algae to irradiance: an analysis of strategies. New Phytol. 93, 157-191. http://dx.doi.org/10.1111/j.14698137.1983.tb03422.x.

Rontani, J.-F., 2001. Visible light-dependent degradation of lipidic phytoplanktonic components during senescence: a review. Phytochemistry 58, 187-202.

Rontani, J.-F., Koblízek, M., Beker, B., Bonin, P., Kolber, Z.S., 2003. On the origin of cis-vaccenic acid photodegradation products in the marine environment. Lipids 38 , 1085-1092.

Rontani, J.-F., Rabourdin, A., Pinot, F., Kandel, S., Aubert, C., 2005. Visible light-induced oxidation of unsaturated components of cutins: a significant process during the senescence of higher plants. Phytochemistry 66, 313-321. http://dx.doi.org/10. 1016/j.phytochem.2004.12.015.

Rontani, J.-F., Zabeti, N., Wakeham, S.G., 2011. Degradation of particulate organic matter in the equatorial Pacific Ocean: biotic or abiotic? Limnol. Oceanogr. 56, 333-349. http://dx.doi.org/10.4319/lo.2011.56.1.0333.

Rontani, J.-F., Charrière, B., Forest, A., Heussner, S., Vaultier, F., Petit, M., Delsaut, N., Fortier L., Sempéré, R., 2012. Intense photooxidative degradation of planktonic and bacterial lipids in sinking particles collected with sediment traps across the Canadian Beaufort Shelf (Arctic Ocean). Biogeosciences 9, 4787-4802. http://dx.doi.org/10.5194/bgd-97743-2012.

Rontani, J.-F., Belt, S.T., Brown, T.A., Vaultier, F., Mundy, C.J., 2014. Sequential photo- and autoxidation of diatom lipids in Arctic sea ice. Org. Geochem. 77, 59-71. http://dx. doi.org/10.1016/j.orggeochem.2014.09.009.

Sandvik, S.L.H., Bilski, P., Pakulski, J.D., Chignell, C.F., Coffin, R.B., 2000. Photogeneration of singlet oxygen and free radicals in dissolved organic matter isolated from the Mississippi and Atchafalaya River plumes. Mar. Chem. 69, 139-152. http://dx.doi. org/10.1016/S0304-4203(99)00101-2.

Schaich, K.M., 1992. Metals and lipid oxidation. Contemporary issues. Lipids 27, 209-218.

Sempéré, R., Yoro, S.C., Van Wambeke, F., Charrière, B., 2000. Microbial decomposition of large organic particles in the northwestern Mediterranean Sea: an experimental approach. Mar. Ecol. Prog. Ser. 198, 61-72.

Sheridan, C.C., Lee, C., Wakeham, S.G., Bishop, J.K.B., 2002. Suspended particle organic composition and cycling in surface and midwaters of the equatorial Pacific Ocean. Deep-Sea Res. I Oceanogr. Res. Pap. 49, 1983-2008.

Sicre, M.A., Paillasseur, J., Marty, J.-C., Saliot, A., 1988. Characterization of seawater samples using chemometric methods applied to biomarker fatty acids. Org. Geochem. 12, 281-288. http://dx.doi.org/10.1016/0146-6380(88)90265-3.

Skovsen, E., Snyder, J.W., Lambert, J.D.C., Ogilby, P.R., 2005. Lifetime and diffusion of singlet oxygen in a cell. J. Phys. Chem. B 109, 8570-8573. http://dx.doi.org/10.1021/ jp051163i.

Smith, D.C., Steward, G.F., Long, R.A., Azam, F., 1995. Bacterial mediation of carbon fluxes during a diatom bloom in a mesocosm. Deep-Sea Res. II Top. Stud. Oceanogr. 42 75-97. http://dx.doi.org/10.1016/0967-0645(95)00005-B.

Suh, H.-J., Lee, H.-W., Jung, J., 2003. Mycosporine glycine protects biological systems against photodynamic damage by quenching singlet oxygen with a high efficiency. Photochem. Photobiol. 78, 109-113.

Suwa, K., Kimura, T., Schaap, A.P., 1977. Reactivity of singlet molecular oxygen with cholesterol in a phospholipid membrane matrix. A model for oxidative damage of membranes. Biochem. Biophys. Res. Commun. 75, 785-792. http://dx.doi.org/10. 1016/0006-291X(77)91541-8.

Tamburini, C., Goutx, M., Guigue, C., Garel, M., Lefèvre, D., Charrière, B., Sempéré, R., Pepa, S., Peterson, M.L., Wakeham, S.G., Lee, C., 2009. Effects of hydrostatic pressure on microbial alteration of sinking fecal pellets. Deep-Sea Res. II Top. Stud. Oceanogr. 56, 1533-1546. http://dx.doi.org/10.1016/j.dsr2.2008.12.035.

Thornton, D.C.O., 2002. Diatom aggregation in the sea: mechanisms and ecological implications. Eur. J. Phycol. 37, 149-161.

Thunell, R., Benitez-Nelson, C., Varela, R., Astor, Y., Muller-Karger, F., 2007. Particulate organic carbon fluxes along upwelling-dominated continental margins: rates and mechanisms. Glob. Biogeochem. Cycles 21, 1-12. http://dx.doi.org/10.1029/ 2006 GB002793.

Turley, C., Mackie, P., 1994. Biogeochemical significance of attached and free-living bacteria and the flux of particles in the NE Atlantic Ocean. Mar. Ecol. Ser. 115 , 191-203.

Veldhuis, M.J.W., Kraay, G.W., Timmermans, K.R., 2001. Cell death in phytoplankton: correlation between changes in membrane permeability, photosynthetic activity pigmentation and growth. Eur. J. Phycol. 36, 37-41.

Viso, A.-C., Marty, J.-C., 1993. Fatty acids from 28 marine microalgae. Phytochemistry 34 1521-1533. http://dx.doi.org/10.1016/S0031-9422(00)90839-2.

Vrieling, E., Poort, L., Beelen, T., Gieskes, W.W.C., 1999. Growth and silica content of the diatoms Thalassiosira weissflogii and Navicula salinarum at different salinities and enrichments with aluminium. Eur. J. Phycol. 34, 307-316.

Westbroek, P., De Jong, E.W., van Der Wal, P., Borman, A.H., De Vrind, J.P.M., Kok, D., De Bruijn, W.C., Parker, S.B., 1984. Mechanism of calcification in the marine alga Emiliania huxleyi. Philos. Trans. R. Soc. Lond. B Biol. Sci. 304, 435-444. http://dx.doi. org/10.1098/rstb.1984.0037.

Whitehead, K., Vernet, M., 2000. Influence of mycosporine-like amino acids (MAAs) on UV absorption by particulate and dissolved organic matter in La Jolla Bay. Limnol. Oceanogr. 45, 1788-1796. http://dx.doi.org/10.4319/lo.2000.45.8.1788.

Wilkinson, F., Helman, W.P., Ross, A.B., 1995. Rate constants for the decay and reactions of the lowest electronically excited singlet state of molecular oxygen in solution. An expanded and revised compilation. J. Phys. Chem. Ref. Data 24, 663. 